\title{
Efficiency of Biostimulants for Alleviating Shade Effects on Forage Grass
}

\author{
Monyck Jeane dos Santos Lopes (Corresponding author) \\ Museu Paraense Emílio Goeldi, Brazil \\ E-mail: monycklopes@museu-goeldi.br \\ Moacyr Bernardino Dias-Filho \\ Brazilian Agricultural Research Corporation (Embrapa), Brazil.
}

Thomaz Henrique dos Reis Castro

Federal Rural University of Amazonia (UFRA), Brazil.

Ely Simone Cajueiro Gurgel

Museu Paraense Emílio Goeldi, Brazil

Gisele Barata da Silva

Federal Rural University of Amazonia (UFRA), Brazil.

Received: May 11, 2021 Accepted: June 10, $2021 \quad$ Published: June 15, 2021

doi:10.5296/jas.v9i3.18611

URL: https://doi.org/10.5296/jas.v9i3.18611

\begin{abstract}
Shade is considered an abiotic stress factor which reduce the primary metabolism and restricts normal growth in forage grass in integrated systems. Biostimulants are beneficial in promoting growth and protecting plants against environmental stresses. This is the first study that links biostimulants and the primary metabolism of plants grown under contrasting light intensities. We investigated how the use of biostimulants modifies the primary metabolism, reducing the deleterious effects of shading in the development of tropical forage grass
\end{abstract}


Brachiaria brizantha cv. BRS Piatã. The association of Pseudomonas fluorescens and Burkholderia pyrrocinia, inoculated by soil drench, were used as biostimulants. We measured leaf anatomy, plant growth, and biochemical parameters. The use of biostimulants increased the shade tolerance on $B$. brizantha by modifying leaf structure, increasing the chlorophyll content, and inducing the production of osmoregulants, such as carbohydrates and proteins. In turn, increasing the accumulation of primary metabolites, promoted root development, plant height, and leaf area, resulting in more vigorous plants with greater biomass production. These results suggested that forage grass can be protected from inhibitory effects of the shade stress by the biostimulants, and this would improve its survival and growth in integrated crop-livestock-forestry systems.

Keywords: Pseudomonas fluorescens, Burkholderia pyrrocinia, light, Brachiaria grass, PGPR

\section{Introduction}

Radiation is essential for the growth, development, and survival of plants. Shade, or low-light conditions, interfere with temperature, soil humidity, and biological interactions, being abiotic stress to plants (Kooke \& Keurentjes, 2012; Valladares et al., 2016). Shade affects the regulation of plant growth, reduces the primary metabolism and restricts normal growth in forage grass in integrated systems (Pimentel et al., 2016). The increasing use of crop-livestock-forest systems requires shade-tolerant forage species, with adaptations to ensure plant survival and high biomass production (Dias-Filho \& Andrade, 2019). Mechanisms of shade tolerance in plants include changes in morphology and biochemistry, which can limit their growth (Valladares et al., 2016; Mundim \& Pringle, 2018). In forage grasses, shade tolerance requires changes in morphology and leaf anatomy which alter forage quality (Pimentel et al., 2016).

Plant biostimulants are substances or microorganisms that promote plant growth (Oosten et al., 2017; Malik et al., 2021; Pacheco et al., 2021). These biostimulants can be used as an alternative to increasing shade tolerance in pasture plants. Plant growth-promoting rhizobacteria (PGPR) act as biostimulants enhancing nutrient uptake, modulating hormones, and mitigating the effects of biotic and abiotic stress (Lopes et al., 2021; Riaz et al., 2021). Biostimulants can mitigate the deleterious effects of shade in Solanum quitoense Lam. (Casierra-Posada et al., 2013); heavy metals contamination of soil in Triticum aestivum L. (Singh et al., 2018); water stress in Cicer arietinum L. (Khan et al., 2019); and saline stress in Arachis hypogaea and Zea mays (Abbas et al., 2019). However, environmental factors, in addition to affecting plant growth, can also affect biostimulants efficiency, as the cost of maintaining symbiosis can outweigh its benefits, turning microorganisms into parasites, slowing plant growth (Odokonyero et al., 2016; Lopes et al., 2018). Therefore, it is necessary to know how growth-promoting rhizobacteria act on the primary metabolism of plants grown under particular stress.

This is the first study that links PGPR inoculation and the primary metabolism of plants grown under different light intensities. Primary metabolites, such as amino acids, proteins, carbohydrates, and organic acids, guarantee the maintenance of cell reproduction and plant 
development (Mundim \& Pringle, 2018, Wang et al., 2019). These osmoregulants increase plant tolerance against environmental stress conditions (Lopes et al., 2021), and shade reduced it is the concentration (Kooke \& Keurentjes, 2012).

Changes in the light environment require the rearrangement of assimilates and photosynthetic metabolites to adapt the plant to its new environment (Valladares et al., 2016; Wang et al., 2019). This rearrangement can affect the morphological, physiological, and biochemical characteristics of plants, such as height, root growth, leaf area, and biomass production. In this study, physiological and biochemical parameters are integrated to elucidate how the interaction between plant and microbe influences plant metabolism. The aim is to understand how these factors are associated to mitigate the deleterious effects of shading on Brachiaria (Syn. Urochloa) brizantha. This information is basic for the selection of plant characteristics that will contribute to a better performance of forage species in tropical integrated crop-livestock-forestry systems.

Therefore, this study on the interaction of rhizobacteria between $B$. brizantha ecophysiology can contribute to establishing management practices consistent with the productive potential of forage plants in low-light environments, ensuring the persistence in integrated systems, and sustainably increasing their productivity. We hypothesize that biostimulants can modify the primary metabolism of $B$. brizantha to mitigate the effects of shading. The aim was to investigate how the use of biostimulants modifies the primary metabolism, reducing the deleterious effect of shading in the development of tropical forage grass Brachiaria brizantha.

Therefore, this study on the interaction of rhizobacteria with the ecophysiology of $B$. brizantha, can contribute to establish management practices consistent with the productive potential of forage plants in low light environments, ensuring the persistence in integrated systems and increasing their productivity in a way sustainable.

Our hypothesis is that biostimulants can modify the primary metabolism of B. brizantha to mitigate the effects of shading. The objective was to investigate how the use of biostimulants modifies the primary metabolism, reducing the deleterious effect of shading on the development of the tropical forage grass Brachiaria brizantha cv. BRS Piata.

\section{Method}

\subsection{Plant Material and Growth Conditions}

The experiment was conducted in a semi-controlled environment in the Federal Rural University of Amazonia (01²7'25 "S, 48²6'36" W), Belém-Pará, Brazil. According to Koppen, the climate classification is Af (equatorial). During the experimental period, the mean air temperature was $32 \pm 2,8^{\circ} \mathrm{C}$ and relative humidity was $73 \pm 3 \%$ (mean \pm s.d.). Seeds of Brachiaria (Syn. Urochloa) brizantha cv. BRS Piatã were sown in polyethylene pots $(15 \times 25$ x $0.5 \mathrm{~cm}$ ) filled with Ferralsol soil ( $\mathrm{pH}, 4,2$; organic matter, 18,80 $\mathrm{g} \mathrm{dm}^{-3} ; \mathrm{P}, 2 \mathrm{mg} \mathrm{dm}^{-3} ; \mathrm{K}, 4$ $\mathrm{mg} \mathrm{dm}{ }^{-3}$; Ca, 0,2 mmolc dm ${ }^{-3}$; $\mathrm{Ca}+\mathrm{Mg}, 0,3 \mathrm{mmolc} \mathrm{dm}^{-3}$; Al, 1,4 mmolc $\mathrm{dm}^{-3}$ ) and kept under greenhouse conditions. Plants were grown under full-sun and artificial shade $(0 \%$ and $47 \%$ of shade, or $2100 \mu$ molm $^{-2} \mathrm{~s}^{-1}$ and $1113 \mu \mathrm{molm}^{-2} \mathrm{~s}^{-1}$ ) obtained with black polyethylene screens. 


\subsection{Biostimulants}

The rhizobacteria Burkholderia pyrrocinia (BRM-32113) and Pseudomonas fluorescens (BRM-32111) were used as biostimulants are preserved in the in vitro collection of the Plant Protection Laboratory, at the Federal Rural University of the Amazon. The bacterial cultured, suspension was prepared and inoculated in plants by soil drench, according to Lopes et al. (2018).

\subsection{Plant Growth Parameters}

At 35 days after seedling emergence (DASE), the plants were collected and the growth parameters were measured (Hunt, 1990; Barbero et al., 2013). The height and culm length were determined and ten plants per treatment were harvested and separated into shoot and roots. The plant material was oven-dried at $60^{\circ}$ until constant mass. Total dry mass was calculated by adding shoot dry mass and root dry mass. SPAD index (soil plant analysis development) was measured in the youngest fully expanded leaf blade (mean of five readings per leaf). A portable chlorophyll meter was used (SPAD-502. Konica Minolta Sensing, INC. Japan). Total leaf area per plant was estimated from specific leaf area and leaf mass results. Specific leaf area (the ratio of leaf area to leaf dry mass) was determined overleaf disks (5 disks per plant) of either $0.42 \mathrm{~cm}^{2}$ or $2.28 \mathrm{~cm}^{2}$, dried at $60^{\circ} \mathrm{C}$ until constant mass.

\subsection{Anatomical Characteristics}

The anatomical study was performed at the Laboratory of Plant Anatomy, in Museu Paraense Emílio Goeldi. At 35 DASE, leaf samples were collected and fixed in FAA solution 50\% (ethanol: glacial acetic acid: formaldehyde). The samples were dehydrated in a graded ethanol series and embedded in hydroxyethyl methacrylate (Leica ${ }^{\circledR}$, Germany). The blocks were cross-sectioned on a rotating microtome Leica RM 2265, with the section of leaves were $5 \mu \mathrm{m}$ thick. Anatomical parameters measured were thickness of the adaxial and abaxial epidermis, and area of the bulliform cells, sclerenchyma, vascular bundles, bundle sheath, mesophyll chlorophyll, xylem, phloem, and the number of vascular bundles. The measurements were carried out under a BX61 Olympus microscope (Japan) and with the software Motic 2.0.

\subsection{Biochemical Analysis}

For measured photosynthetic pigments were used 10mg of fresh leaves and ethanol solutions. The absorbance of the samples was determined at 645 and $665 \mathrm{~nm}$ (Lopes et al., 2020). Total soluble carbohydrates and starch content were determined using the $50 \mathrm{mg}$ of dry matter and the quantification of the total soluble carbohydrates at $490 \mathrm{~nm}$, using glucose as a standard (Dubois et al., 1956). Ammonium content was determined in a sample of $50 \mathrm{mg}$ of dry matter and quantification was carried out at $625 \mathrm{~nm}$, with $\left(\mathrm{NH}_{4}\right)_{2} \mathrm{SO}_{4}$ as standard (Weatherburn, 1967). Nitrate content was measured in a sample of $100 \mathrm{mg}$ of dry matter and quantification was carried out at $410 \mathrm{~nm}$, with $\mathrm{KNO}_{3}$ as standard (Cataldo et al., 1975). Amino acid and total soluble protein contents were determined using the $10 \mathrm{mg}$ of fresh leaves. The absorbance was measured amino acid was at $570 \mathrm{~nm}$. The calibration curve was made using Leucine (1mM) (Gibon et al., 2004). Quantification of the total soluble proteins was carried out at $595 \mathrm{~nm}$, and albumin bovine was used as a standard (Bradford, 1976). 


\section{1) Macrothink}

\subsection{Statistical Analyses}

The experimental design was completely randomized in $2 \times 2$ factorial arrangements (non-inoculated B. brizantha and co-inoculated (B. pyrrocinia + P. fluorescens) $\mathrm{x}$ full-sun and shade), with ten replicates. Data were subjected to analysis of variance and means compared by the Duncan test $(\mathrm{P}<0.05)$. Statistical analyses were performed by the STATISTICA (StatSoft, Inc., Tulsa, USA).

\section{Results}

Biostimulants were able to modify the metabolism of B. brizantha, changing its leaf structure so that the ambient light was used most efficient, resulting in more vigorous plants, with greater height and biomass production under full sun and shade $\left(\mathrm{F}_{1,20}=517.23 ; \mathrm{P}<0.01\right)$ (Figure 1).
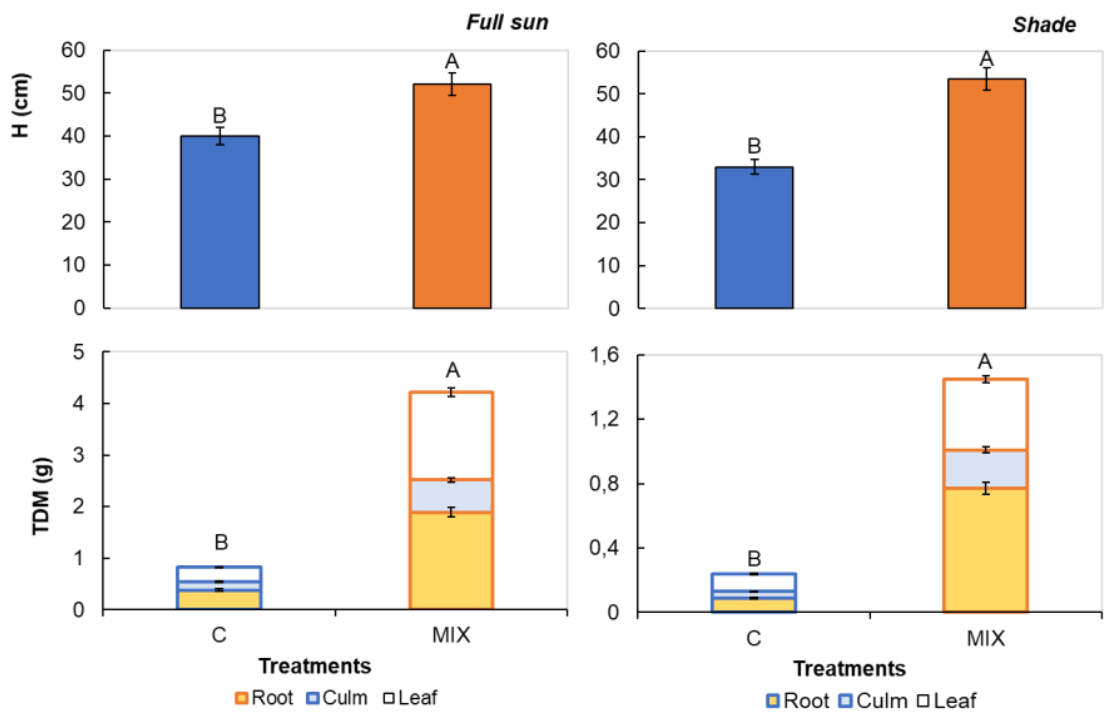

Figure 1. Effect of biostimulants and light on dry mass production (TDM) and plant height (H) of Brachiaria brizantha. Error bars represent standard errors of the mean $(n=10)$. Different letters are indicating significant differences $(\mathrm{P}<0.05)$ among treatments $(\mathrm{C}=$ non-biostimulants; Mix $=$ Burkholderia pyrrocinia + Pseudomonas fluorescens $)$

Under full sun, inoculated plants showed similar biomass partition between leaves and roots. Under the shade, inoculated plants increase biomass allocation to roots (Figure 1). Under full sun and shade, the use of biostimulants also favored an increased in the SPAD index, chlorophyll concentration, especially chlorophyll b (Figure 2), and leaf area ( $\mathrm{P}<0.01)$ (Figure 3). Biostimulants reduced specific leaf area in $B$. brizantha under both light intensities $\left(\mathrm{F}_{1,20}=\right.$ 113.8; P <0.01) (Figure 3). 

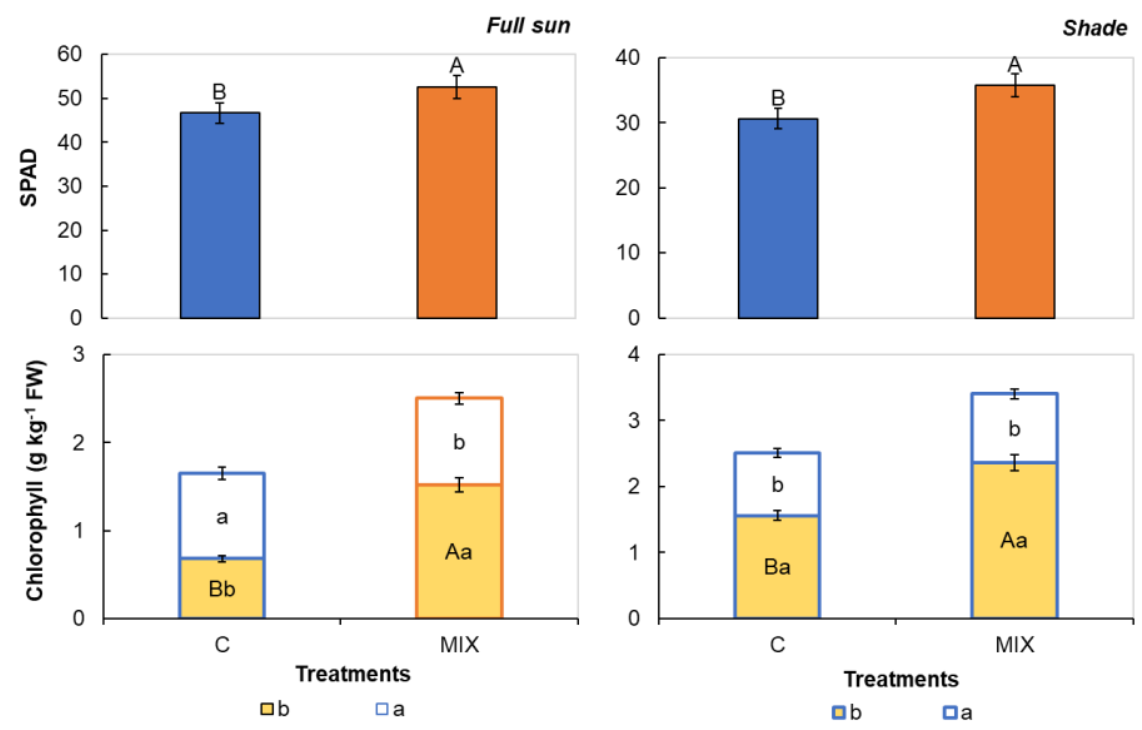

Figure 2. Effect of biostimulants and light on SPAD index and chlorophyll total $(a+b)$ of Brachiaria brizantha. Error bars represent standard errors of the mean $(\mathrm{n}=10)$. Different lowercase letters within columns indicate significant differences among shoot and root. Different upper-case letters are indicating significant differences $(\mathrm{P}<0.05)$ among treatments $(\mathrm{C}=$ non-biostimulants; Mix $=$ Burkholderia pyrrocinia + Pseudomonas fluorescens $)$
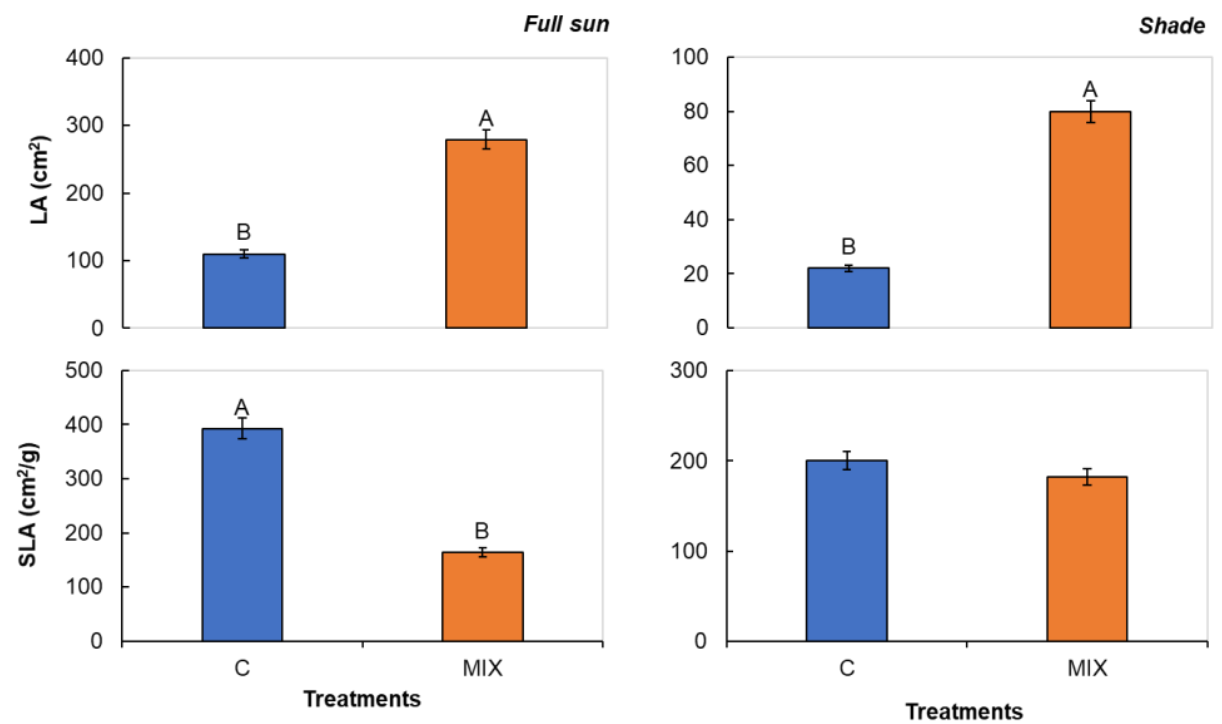

Figure 3. Effect of biostimulants and light on leaf area (LA) and specific leaf area (SLA) of Brachiaria brizantha. Error bars represent standard errors of the mean $(\mathrm{n}=10)$. Different letters are indicating significant differences $(\mathrm{P}<0.05)$ among treatments $(\mathrm{C}=$ non-biostimulants; Mix $=$ Burkholderia pyrrocinia + Pseudomonas fluorescens $)$

Biostimulants modified leaf anatomy. In the cross-sections of leaf blades of inoculated plants, it was possible to observe increased leaf thickness (Figure 4; Table 1). Inoculation also resulted in larger vascular bundles area, sheath cells, vascular sheath, and chlorophyll 


\section{MInstitute ${ }_{\text {Mnim }}^{\text {Macrothin }}$}

mesophyll, regardless of the light intensity in which plants were grown $(\mathrm{P}<0.01)$ (Table 1).
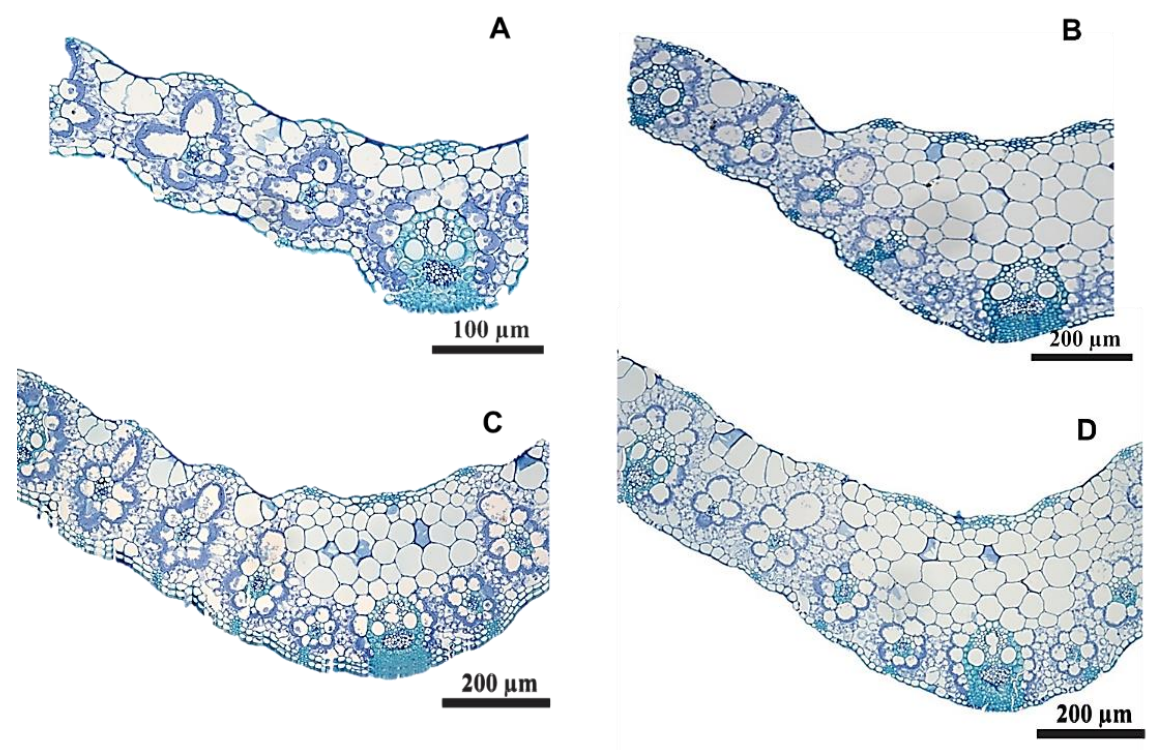

Figure 4. Brachiaria brizantha cross sections leaf. Plants under shade (a,b) and full sun (c,d). Non-biostimulants $((a, c)$ and biostimulants plants $(b, d)$

Under both full sun and shade, inoculated plants showed higher carbohydrates $\left(\mathrm{F}_{1,20}=122.8\right.$; $\mathrm{P}<0.001)$ and starch content $\left(\mathrm{F}_{1,20}=463.6 ; \mathrm{P}<0.01\right)$ (Figure 5). Inoculated full-sun plants showed higher carbohydrates and starch concentration in the shoot (Figure 5), while in inoculated shade plants carbohydrate partition was similar between shoot and root and starch concentration was higher in shoots (Figure 5).
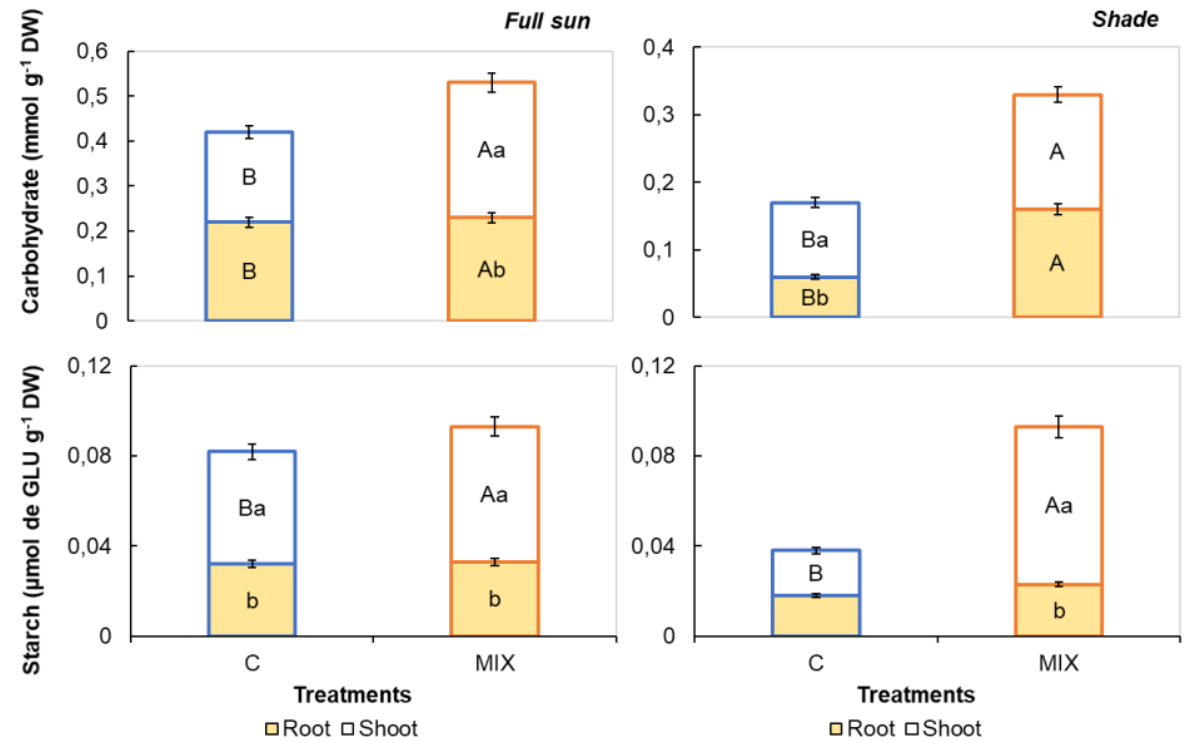

Figure 5. Effect of biostimulants and light on carbohydrate and starch of Brachiaria brizantha. Error bars represent standard errors of the mean $(n=10)$. Different lowercase letters within columns indicate significant differences among shoot and root. Different 
upper-case letters are indicating significant differences $(\mathrm{P}<0.05)$ among treatments $(\mathrm{C}=$ non-biostimulants; Mix $=$ Burkholderia pyrrocinia + Pseudomonas fluorescens)

Table 1. Biostimulants and light intensity on anatomical parameters of Brachiaria brizantha.

\begin{tabular}{lll} 
Parameters Non-biostimulants $\quad$ Biostimulants \\
\hline
\end{tabular}

\section{Full sun}

Thickness $(\mu \mathrm{m})$

Adaxial epidermis $(\mu \mathrm{m})$

Abaxial epidermis $(\mu \mathrm{m})$

Bulliform cells area $\left(\mu \mathrm{m}^{2}\right)$

Xylem area $\left(\mu \mathrm{m}^{2}\right)$

Phloem area $\left(\mu \mathrm{m}^{2}\right)$

Sclerenchyma area $\left(\mu \mathrm{m}^{2}\right)$

Vascular bundles area $\left(\mu \mathrm{m}^{2}\right)$

Bundle sheath area $\left(\mu \mathrm{m}^{2}\right)$

Mesophyll chlorophyll area $\left(\mu \mathrm{m}^{2}\right)$
$48,48 \mathrm{~b}$

$2,29 \mathrm{~b}$

$2,36 b$

$112,51 \mathrm{~b}$

$359,56 \mathrm{~b}$

$338,25 \mathrm{~b}$

$90,81 \mathrm{~b}$

86,42 b

$422,40 \mathrm{~b}$

104,68 b
100,86 a

$5,24 \mathrm{a}$

5,09 a

319,76 a

489,98 a

411,91 a

234,36 a

245,38 a

950,94 a

889,87 a

Shade

Thickness $(\mu \mathrm{m})$

$38,14 b$

87,59 a

Adaxial epidermis $(\mu \mathrm{m})$

$1,09 \mathrm{~b}$

$4,54 \mathrm{a}$

Abaxial epidermis $(\mu \mathrm{m})$

$2,86 \mathrm{~b}$

$4,87 \mathrm{a}$

Bulliform cells area $\left(\mu \mathrm{m}^{2}\right)$

$54,41 \mathrm{~b}$

57,97 a

Xylem area $\left(\mu \mathrm{m}^{2}\right)$

$4,76 \mathrm{~b}$

26,95 a

Phloem area $\left(\mu \mathrm{m}^{2}\right)$

6,10 a 


\section{Macrothink Institute $^{\mathrm{TM}}$}

Sclerenchyma area $\left(\mu \mathrm{m}^{2}\right)$

Vascular bundles area $\left(\mu \mathrm{m}^{2}\right)$

Bundle sheath area $\left(\mu \mathrm{m}^{2}\right)$

Mesophyll chlorophyll area $\left(\mu \mathrm{m}^{2}\right)$
Journal of Agricultural Studies

ISSN 2166-0379 2021, Vol. 9, No. 3

$2,33 \mathrm{~b}$

17,16 a

$5,42 \mathrm{~b}$

65,72 a

24,47 b

130,87 a

58,46 a

Irrespective of inoculation and light regime $B$. brizantha showed higher ammonium concentration in roots, and more nitrate and amino acids in the shoot (Figure 6). Inoculated full-sun plants had higher ammonium content in roots, while nitrate was equally distributed between shoots and roots (Figure 6). In shade, the inoculated plants had lower ammonium and a higher nitrate concentration, and two metabolites concentration was higher in the shoot (Figure 6). Inoculated plants, under both sun and shade environments, had lower amino acids and a higher protein concentration, both with a greater allocation to shoots $\left(\mathrm{F}_{1,20}=24.69\right.$; $\mathrm{P}<0.01$ and $\mathrm{F}_{1,20}=13.7 ; \mathrm{P}<0.01$, respectively), as shown in Figure 7.
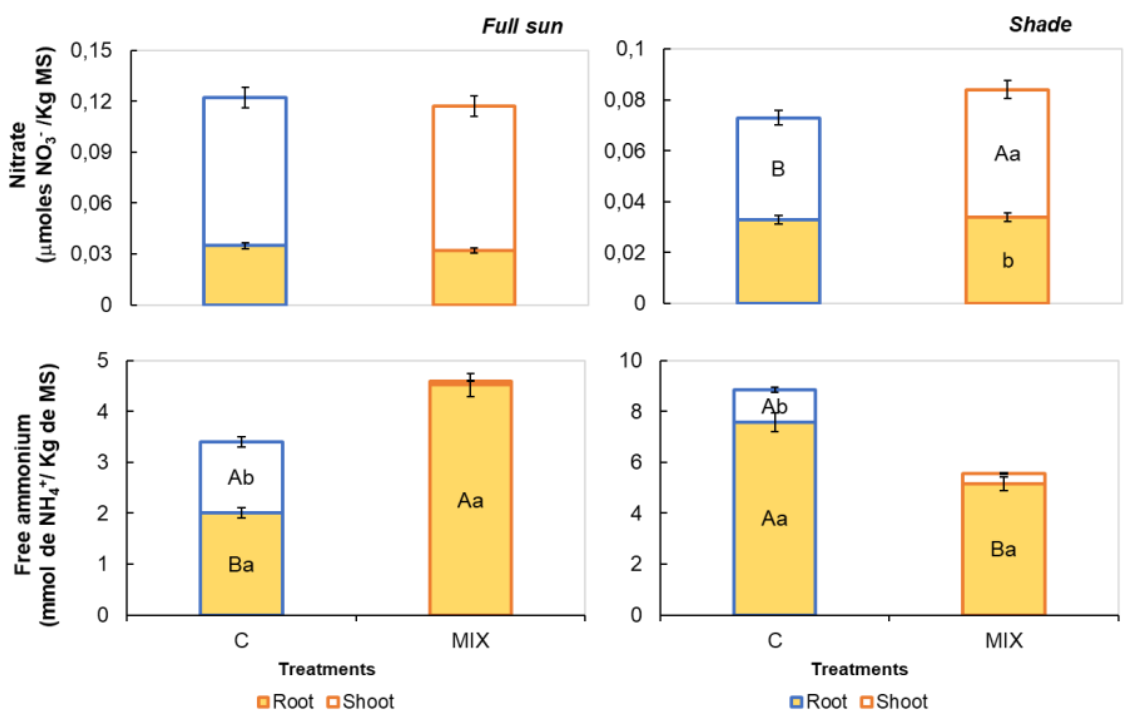

Figure 6. Effect of biostimulants and light on nitrate and free ammonium of Brachiaria brizantha. Error bars represent standard errors of the mean $(n=10)$. Different lowercase letters within columns indicate significant differences among shoot and root. Different upper-case letters are indicating significant differences $(\mathrm{P}<0.05)$ among treatments $(\mathrm{C}=$ non-biostimulants; Mix = Burkholderia pyrrocinia + Pseudomonas fluorescens) 

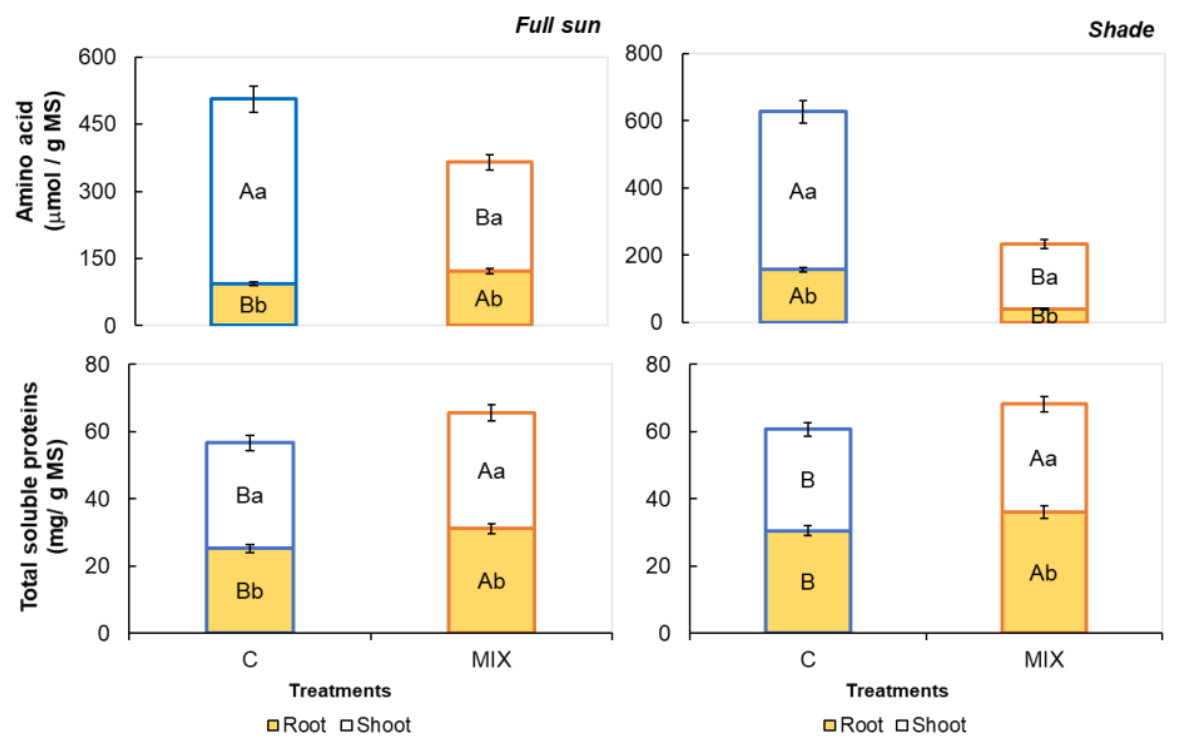

Figure 7. Effect of biostimulants and light on amino acid and proteins of Brachiaria brizantha. Error bars represent standard errors of the mean $(n=10)$. Different lowercase letters within columns indicate significant differences among shoot and root. Different upper-case letters are indicating significant differences $(\mathrm{P}<0.05)$ among treatments $(\mathrm{C}=$ non-biostimulants; Mix = Burkholderia pyrrocinia + Pseudomonas fluorescens)

Shade reduced the growth and development of $B$. brizantha, but the use of biostimulants mitigated the effect of shading on plant development (Table 2). Regardless of light intensity, the use of biostimulants increased biomass production, which was linearly correlated (P $<0.05$ ) with SPAD index, leaf area, height, chlorophyll $b$, primary metabolites, and mesophyll chlorophyll area (Table 2). 
Table 2. Biostimulants and light on percentage increase of Brachiaria brizantha

\begin{tabular}{|c|c|c|}
\hline Parameters & Full sun & Shade \\
\hline Leaf dry mass & 507 & 264 \\
\hline Culm dry mass & 294 & 500 \\
\hline Root dry mass & 397 & 755 \\
\hline Total dry mass & 402 & 476 \\
\hline Leaf area & 154 & 265 \\
\hline Height & 30 & 62 \\
\hline SPAD index & 13 & 17 \\
\hline Chlorophyll b & 123 & 51 \\
\hline Carbohydrate shoot & 50 & 54 \\
\hline Carbohydrate root & - & 167 \\
\hline Starch shoot & 20 & 250 \\
\hline Free ammonium root & 126 & - \\
\hline Nitrate shoot & - & 25 \\
\hline Total soluble proteins shoot & 10 & 7 \\
\hline Total soluble proteins root & 24 & 20 \\
\hline
\end{tabular}

\section{Discussion}

The B. pyrrocinia and P. fluorescens acted as biostimulants, promoted the highest in nitrogen content, increasing the chlorophyll concentration, primary metabolites content, such as sugars and proteins, resulting in more vigorous and productive plants under light intensity, and also increased shade tolerance in B. brizantha (Figure 8).

Environmental stress can affect the survival, diversity of microbes, and plant growth-promoting microbes potential to improve plant growth and stress tolerance (Lopes et al. 2021). This is observed in Brachiaria inoculated with Sarocladium implicatum. According 
to Odokonyero et al. (2016), this interaction was not beneficial, S. implicatum has a higher metabolic cost, does not attenuate the effects of water stress, reduces the biomass and carbohydrates content, affecting the quality and production in Brachiaria.

Furthermore, shade reduces the products of photosynthesis, concentrations of metabolites, plant growth, and production of biomass mainly on $\mathrm{C} 4$ forage plants, such as $B$. brizantha (Gobbi et al., 2011; Pimentel et al., 2016), Phalaris aquatica (Ciavarella et al., 2000) and Trichloris crinite (Cavagnaro \& Trione, 2007).

Our results support the idea of functional stability in the forage grass - biostimulants interaction facing disturbances. In the present study, it was observed that the use of bioinoculants was beneficial to increase growth, physiological plasticity, and shade tolerance in B. brizantha.

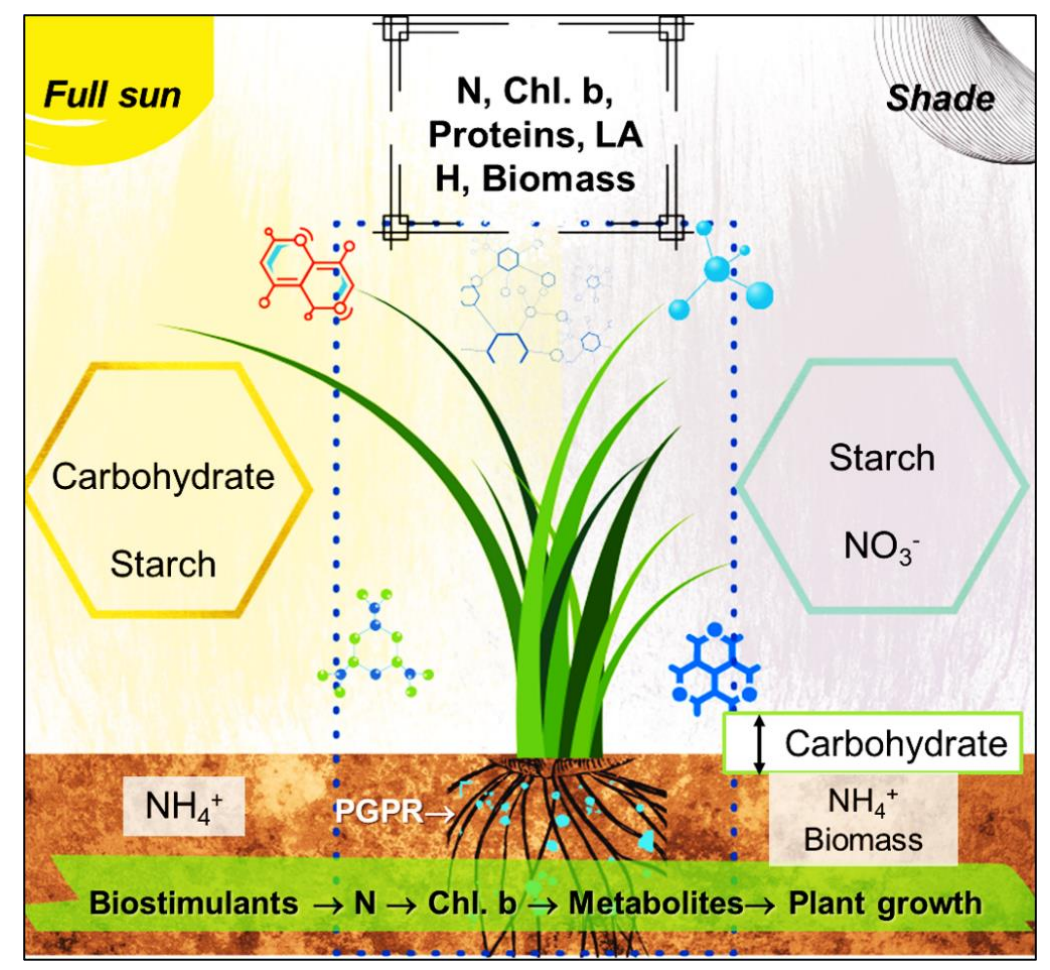

Figure 8. Summary of main key mechanisms of biostimulants (PGPR) on Brachiaria brizantha growth under full sun and shade. Nitrogen $(\mathrm{N})$; leaf area (LA); plant height $(\mathrm{H})$; nitrate ( $\left.\mathrm{NO}_{3}-\right)$; ammonium ( $\left.\mathrm{NH}_{4+}\right)$; Chlorophyll b (Chl. b)

Biostimulants improved morphological adaptations to increase shade tolerance in $B$. brizantha, such as the increase in the leaf area, and ecophysiological mechanism which allows the increase in the photosynthetic surface to absorb light (Taiz \& Zeiger, 2017; Gobbi et al., 2011; Valladares et al., 2016). In the present study, the use of bioinoculants increased leaf thickness and biomass by about $500 \%$ in full-sun plants and over $200 \%$ in shade plants, reducing the specific leaf area in both light environments (Table 2).

Anatomical leaf changes in inoculated plants increased light capture and shade tolerance. The greater efficiency in capturing light, followed by better photochemical use of inoculated 
plants, reflected an increase of around $400 \%$ in total biomass production, irrespective of light intensity (Table 2). Inoculated plants showed an increase in bulliform cells. This characteristic would increase Brachiaria is resistance to water stress (Gobbi et al., 2011). These changes in the leaf internal structure affected the metabolic routes that determine the amount of carbon fixed in the chloroplasts and sugar allocation and transport, resulting in higher carbohydrate and starch concentration in these plants. In Brachiaria decumbens cv. Basilisk, shade also increased specific leaf area, which was granted to a reduction in leaf thickness, vascular bundles, and bulliform cell areas (Gobbi et al., 2011).

A significant increase in the chlorophyll content in plant biostimulants, mainly chlorophyll b, optimized the absorption of photosynthetically active radiation. This is because chlorophyll $b$ absorbs energy at wavelengths greater than chlorophyll a in plants under shade (Gonçalves et al., 2001; Taiz \& Zeiger, 2017). The increase in chlorophyll has also been reported in Trichloris crinite grown under shade (Cavagnaro \& Trione, 2007), Triticum aestivum L. (Singh et al., 2018), and Cicer arietinum L. with biostimulants (Khan et al., 2019).

Biostimulants are also beneficial in mitigating other effects of abiotic stresses, by increase the photosynthetic pigments, carbohydrates, proteins concentrations, and total biomass (Lopes et al., 2021), as related in Cicer arietinum L. (Khan et al., 2019) and Triticum aestivum L. (Singh et al., 2018) both under drought. Our results showed that the biostimulants attenuated the effect of shading by the accumulation of sugars, resulting in a higher concentration of starch, carbohydrate, and nitrogen, increasing biomass production.

In the present study, plant biostimulants also had a higher SPAD index, suggesting higher nitrogen content. Nitrogen is an essential nutrient to forage growth, influences leaf area development and the carbohydrates allocation, can direct carbohydrate to the secondary metabolism, synthesizing it in lignin, an indigestible compound to animals (Gobbi et al., 2011). The nitrogen absorbed is metabolized in the roots or xylem transported to the shoot, being preferentially absorbed in the form of nitrate $\left(\mathrm{NO}_{3}{ }^{-}\right)$and ammonium $\left(\mathrm{NH}_{4}{ }^{+}\right)$(Taiz \& Zeiger, 2017). In this study, regardless of the treatment, ammonium was assimilated in the roots, while nitrate was transported to shoot in B. brizantha. Once assimilated, nitrogen was converted into other organic compounds, which resulted in an increase in amino acids and proteins in plants inoculated with biostimulants.

Carbohydrate accumulation in the shoot of inoculated plants, in this study, may have acted as a means to activate the gene expression related to photosynthetic activities (Odokonyero et al., 2016; Khan et al., 2019). To survival under stress, the plant can use mechanisms, as the increase in carbohydrates which acts as an osmotic regulator and increases starch content, which is an energy reserve (Oosten et al., 2017; Hennion et al., 2019). Therefore, the higher accumulation of primary metabolites in inoculated plants also mitigated the effects of shade. The increase in carbohydrate and starch contents are also beneficial in forage grasses to improve palatability, protein content and dry matter consumption, allowing higher weight gain and milk production (Ciavarella et al., 2000; Barbero et al., 2013).

Sugars also regulate root elongation, modeling the plasticity of root architecture in response to environmental factors (Caretto et al., 2015; Hennion et al., 2019). Previous research shows 
that shade decreases total dry mass production and reduces the amount of carbon allocated to roots (Pimentel et al., 2016). In the present study, the increase in root biomass observed in inoculated shade plants suggests that the use of biostimulants potentiated water and nutrients absorptions, improving plant growth under shade. Bioinoculants also increased root biomass in Cicer arietinum L. (Khan et al., 2019). The fact that inoculated B. brizantha allocated more biomass to roots, could make them more tolerant to grazing, increasing pasture longevity (Pimentel et al., 2016; Lopes et al., 2018).

\section{Conclusions}

The use of bioinoculants increased the shade tolerance on B. brizantha by modifying leaf structure, increase the chlorophyll content, and inducing the production of osmoregulants, such as carbohydrates and proteins. In turn, increasing the accumulation of primary metabolites, promoted root development, plant height, and leaf area, resulting in more vigorous plants with greater biomass production. These results suggested that the use of biostimulants can reduce the deleterious effect of shading in forage grass, which would improve its survival and growth in integrated crop-livestock-forestry systems. Studies of multiple resource limitations (e.g., combined nutrient, drought, and flooding) are still essential and may improve our understanding and management of pasture ecosystems.

\section{Acknowledgments}

We thank Federal Rural University of Amazonia (UFRA), Fundação Amazônia de Amparo a Estudos e Pesquisa do Pará (FAPESPA) and Museu Paraense Emílio Goeldi (MPEG) for support this research materially, financially and laboratory. We also thank Francisco Janyelo Palacios Martinez (in memorian), from Grupo Gasparim, for kindly supplying the Brachiaria brizantha cv. BRS Piatã seeds. Thanks Walter Velasco, Lenison Ferreira and Cândido Oliveira Neto for technical laboratory support; and Bruno Carneiro e Pedreira from Embrapa Agrossilvipastoril for performing the nutritive and mineral analyzes.

\section{References}

Abbas, R., Rasula, S., Aslam, K., ... Naqqash, T. (2019). Halotolerant PGPR: A hope for cultivation of saline soils. Journal of King Saud University-Science, 31(4), 1195-1201. https://doi.org/10.1016/j.jksus.2019.02.019

Barbero, L. M., Prado, T. F., Basso, K. C., ... Silva, G. A. S. (2013). Análise de crescimento em plantas forrageiras aplicada ao manejo de pastagens. Veterinária Notícias 19(2), 71-85.

Bradford, M. M. (1976). A rapid and sensitive method for the quantitation of microgram quantities of protein utilizing the principle of protein-dye binding. Analytical Biochemistry, 72, 248-254. https://doi.org/10.1016/0003-2697(76)90527-3

Caretto, S., Linsalata, V., Colella, G., Mita, G., \& Lattanzio, V. (2015). Carbon fluxes between primary metabolism and phenolic pathway in plant tissues under stress. International Journal of Molecular Sciences, 16, 26378-26394. https://doi.org/10.3390/ijms161125967 
Casierra-Posada, F., Peña-Olmos, J., Peñaloza, J., \& Roveda, G. (2013). Influencia de la sombra y de las micorrizas sobre el crecimiento de plantas de lulo (Solanum quitoense Lam.). Revista UDCA Actualidad \& Divulgación Científica, 16, 61-70. https://doi.org/10.31910/rudca.v16.n1.2013.859

Cataldo, D. A., Haroon, S. L. E., \& Yougs, V. L., 1975. Rapid colorimetric determination of nitrate in plant tissue by nitration of salicylic acid. Communications in Soil Science and Plant Analysis, 6, 71-80. https://doi.org/10.1080/00103627509366547

Cavagnaro, J. B., \& Trione, S. O. (2007). Physiological, morphological and biochemical responses to shade of Trichloris crinita, a forage grass from the arid zone of Argentina. $\begin{array}{llll}\text { Journal of Arid } \quad \text { Environments, } & \text { 68(3), }\end{array}$ https://doi.org/10.1016/j.jaridenv.2006.06.004

Ciavarella, T. A., Simpson, R. J., Dove, H., Leury, B. J., \& Sims, I. M. (2000). Diurnal changes in the concentration of water-soluble carbohydrates in Phalaris aquatica L. pasture in spring, and the effect of short-term shading. Australian Journal of Agricultural Research, 51(6), 749. https://doi.org/10.1071/ar99150

Dias-Filho, M. B., \& Andrade, C. M. S. (2019). Recuperação de pastagens degradadas na Amazônia. Brasília, DF: Embrapa, p.443.

Dubois, M., Guilles, K.A., Hamilton, J.K., ... Smith F. (1956) Calorimetric method for the determination of sugars and related substances. Analytical Chemistry, 18, 350-356. https://oi.org/10.1021/ac60111a017

Gibon, Y., Blaesing, O. E., Hannemann, J, ... Stitt, M. (2004). A robot-based platform to measure multiple enzyme activities in Arabidopsis using a set of cycling assays: comparison of changes of enzyme activities and transcript levels during diurnal cycles and in prolonged darkness. Plant Cell, 16, 3304-3325. https://doi.org/10.1105/tpc.104.025973

Gobbi K. F., Garcia, R., Ventrella, M. C., Garcez Neto, \& A. F., Rocha, G. C. (2011). Área foliar específica e anatomia foliar quantitativa do capim-braquiária e do amendoim-forrageiro submetidos a sombreamento. Revista Brasileira de Zootecnia, 40(7), 1436-1444. https://doi.org/10.1590/S1516-35982011000700006

Hennion, N., Durand, M., Vriet, C., ... Pourtau, N. (2019). Sugars a route to the roots. Transport, metabolism and storage within plant roots and towards microorganisms of the rhizosphere. Physiologia Plantarum, 165, 44-57. https://doi.org/10.1111/ppl.12751

Hunt, R (1990) Basic growth analysis for beginners, London. https://doi.org/10.1007/978-94-010-9117-6

Khan, N., Bano, A., Rahman, M. A., ... Babar, M. A. (2019). Comparative physiological and metabolic analysis reveals a complex mechanism involved in drought tolerance in chickpea (Cicer arietinum L.) induced by PGPR and PGRs. Scientific Reports, 9(2097), 1-19. https://doi.org/10.1038/s41598-019-38702-8 1

Kooke, R., \& Keurentjes, J. J. B. (2012). Multi-dimensional regulation of metabolic networks 
shaping plant development and performance. Journal of Experimental Botany, 63(9), 3353-3365. https://doi.org/10.1093/jxb/err373

Lopes, M. J. S., Dias-Filho, M. B, Castro, T. H. R., \& Silva, G. B. (2018). Light and plant growth-promoting rhizobacteria effects on Brachiaria brizantha growth and phenotypic plasticity to shade. Grass and Forage Science 73(2), 493-499. https://doi.org/10.1111/gfs.12336

Lopes, M. J. S., Dias-Filho, M. B., Castro, T. H. R., ... Silva, G. B. (2020). Impacts of plant growth promoting rhizobacteria on tropical forage grass in Brazil. Journal of Agricultural Studies, 8(1), 342-356. https://doi.org/10.5296/jas.v8i1.16077

Lopes, M. J. S., Dias-Filho, M. B., \& Gurgel, E. S. C. (2021). Successful plant growth-promoting microbes: inoculation methods and abiotic factors. Frontiers in Sustainable Food Systems, 5, 606454, 1-13. https://doi.org/10.3389/fsufs.2021.606454

Malik, A., Mor, V.S., Tokas, J., Punia, H., Malik, S., ... Karwasra, A. (2021). Biostimulant-treated seedlings under sustainable agriculture: a global perspective facing climate change. Agronomy, 11, 14. https://doi.org/10.3390/agronomy11010014

Mundim, F.M., \& Pringle, E.G. (2018). Whole-plant metabolic allocation under water stress. Frontiers Plant Science, 9, 852. https://doi.org/10.3389/fpls.2018.00852

Odokonyero, K., Acuña, T. B., Cardoso, J. A., Jimenez, J. C., \& Rao, I. M. (2016). Fungal endophyte association with Brachiaria grasses and its influence on plant water status, total non-structural carbohydrates and biomass production under drought stress. Plant Soil, 409, 273-282. https://doi.org/10.1007/s11104-016-2947-5

Oosten, M. J. V., Pepe, O., Pascale, S. ... Maggio, A. (2017). The role of biostimulants and bioeffectors as alleviators of abiotic stress in crop plants. Chemical and Biological Technologies in Agriculture, 4(5), 1-12. https://doi.org/10.1186/s40538-017-0089-5

Pacheco, I., Ferreira, R., Correia, P., ... Cruz, C. (2021). Microbial consortium increases maize productivity and reduces grain phosphorus concentration under field conditions. Saudi J. Biol. Sci., 28(1), 232-237. https://doi.org/10.1016/j.sjbs.2020.09.053

Pimentel, R.M., Bayão, G.F.V., Lelis, D.L., ... Santos M. E. R. (2016). Ecofisiologia de plantas forrageiras. Publicações em Medicina Veterinária e Zootecnia, 10(9), 666-679. https://doi.org/10.22256/pubvet.v10n9.666-679

Riaz U., Murtaza G., Anum W., ... Nazir M. Z. (2021). Plant growth-promoting rhizobacteria (PGPR) as biofertilizers and biopesticides. In: Hakeem K.R., Dar G.H., Mehmood M.A., Bhat R.A. (eds) Microbiota and Biofertilizers. Springer, Cham. https://doi.org/10.1007/978-3-030-48771-3_11

Singh, R. P., Mishra, S., Jha, P., Raghuvanshi, S., \& Jha, P. N. (2018). Effect of inoculation of zinc-resistant bacterium Enterobacter ludwigii CDP-14 on growth, biochemical parameters and zinc uptake in wheat (Triticum aestivum L.) plant. Ecological Engineering, 116, 163-173. https://doi.org/10.1016/j.ecoleng.2017.12.033 


\section{IIMacrothink}

Journal of Agricultural Studies

ISSN 2166-0379 2021, Vol. 9, No. 3

Taiz, L., \& Zeiger, E. (2017). Fisiologia e Desenvolvimento Vegetal, 6th Edn. Porto Alegre: Artmed, 888p.

Valladares, F., Laanisto, L., Niinemets, \& Ü., Zavala, M.A., 2016. Shedding light on shade: ecological perspectives of understored plant life. Plant Ecology \& Diversity, 9(3), 237-251. https://doi.org/10.1080/17550874.2016.1210262

Wang, S., Alseekh, S., Fernie, A.R., \& Luo, J. (2019). The Structure and Function of Major Plant Metabolite Modifications. Molecular Plant, 12, 899-919. https://doi.org/10.1016/j.molp.2019.06.001

Weatherburn, M.W. (1967). Phenol hypochlorite reaction for determination of ammonia. Analytical Chemistry, 39, 971-974. https://doi.org/10.1021/ac60252a045

\section{Copyright Disclaimer}

Copyright for this article is retained by the author(s), with first publication rights granted to the journal.

This is an open-access article distributed under the terms and conditions of the Creative Commons Attribution license (http://creativecommons.org/licenses/by/4.0/). 